\title{
Comparative Analysis of the Stability of Money Demand between Côte d'Ivoire And Ghana: An Application of ARDL Model
}

\author{
Yao Kouadio Ange-Patrick ${ }^{1} \&$ Drama Bédi Guy Hervé ${ }^{1}$ \\ ${ }^{1}$ Département de Sciences Economiques et de Gestion Université Peleforo Gon, Korhogo, République de Côte \\ d'Ivoire \\ Correspondence: Drama Bédi Guy Hervé, Département de Sciences Economiques et de Gestion Université \\ Peleforo Gon, Korhogo, République de Côte d'Ivoire. E-mail: dramsiben.upgck@ gmail.com
}

Received: September 2, 2017

Accepted: October 14, 2017

Online Published: October 25, 2017

doi:10.5539/ijef.v9n11p163

URL: https://doi.org/10.5539/ijef.v9n11p163

\begin{abstract}
This paper empirically examined the broad money demand function and its stability in two West African countries namely Cote d'Ivoire and Ghana covering the period of 1980 to 2015 using the Autoregressive Distributed Lag (ARDL) Bounds testing procedure. The empirical results confirm the stability of the money demand function and support the choice of $M_{2}$ as a viable instrument for policy implementation in both countries cited above. The study also demonstrates that a long-run relationship exists between money aggregate $\left(M_{2}\right)$ and its determinants during the study period. In fact, the real income tends to be the most significant factor explaining the demand for broad money in both countries. In addition, the overall short run estimation of our model is statistically significant for Cote d'Ivoire and insignificant for Ghana at the conventional level. This means that money demand is stable for Cote d'Ivoire in short run and unstable for Ghana in the same period. It is recommended that monetary policy authorities should continue to implement policies that will reinforce macroeconomic stability and facilitate economic growth.
\end{abstract}

Keywords: money demand, ARDL approach, Côte d'Ivoire, Ghana, bounds test, stability

\section{Introduction}

Analyze the demand for money in an economy is to try to find the motives that motivate the agents to prefer the holding of liquidity to other assets. Such analysis implies a good knowledge of the structure of the portfolio available to economic agents as well as a certain idea of what they could gain or lose by holding their wealth in a form other than money. The function of demand for money is an essential element of monetary policy. Indeed, a good knowledge of the variables significantly determining the preference for liquidity helps to inform the authorities on the best way to manage the money supply without introducing economic distortions. Similarly, a good knowledge of the agents' ability to adjust their demand for money to shocks provides to these authorities an idea of the effectiveness of their interventions. However, for the results to be a reliable basis, the estimated function should be stable. The first models of demand for money conceived in the developing countries argue that the quantitative theory is considered to be the most realistic in these economies. They thus favour the transaction motive (Polak, 1957; Polak \& Argny, 1971). While the role of money as a store of value is sometimes recognized in these models (especially through the precautionary motive), speculation is generally considered a negligible motive. The omission of a relevant variable introduces significant biases into the econometric estimation, which is one of the causes of instability of money demand functions. Another source of this instability lies in the choice of an inappropriate estimation method, which occurs whenever traditional econometrics are used in the presence of non-stationary time series.

The literature has attempted to fill these gaps in two main directions. On the one hand, it broadens the number of determinants of liquidity preference to take better account of the economic and financial environment in which the wealth held by economic agents can be developed. On the other hand, it tries to constantly improve the estimation methods in order to arrive at better established econometric results. Economic agents in Cote d'Ivoire operate in the West African Economic and Monetary Union (UEMOA), characterized by a common monetary policy, a coherent institutional framework and a relatively low level of monetization and intermediation. Concerning Ghana, since the implementation of the Economic Recovery Programme (ERP) in April 1983, several important reforms have been conducted into the economy of Ghana with the objective of macroeconomic 
stability and sustained growth. In so doing, the main objective of the Central Bank of Ghana is to keep low inflation and stable money demand. Given these characteristics that influence the behaviour of economic agents, it is important to ask what are the determinants of money demand in Cote d'Ivoire and Ghana? The main objective of our research is therefore to highlight the main variables that determine the demand for money in both countries. The rest part of the paper is organized as follow. Section 2 deals with the literature review and theoretical framework. Section 3 outlines empirical model specification, methodology applied and data sources. Empirical results and interpretations are highlighted in section 4. Then the last section deals with the concluding part and policy implication.

\section{Literature Review about Money Demand Function}

As we know it's theoretically and empirically justified that the equilibrium linkage between money demand and its determinants plays a significant role in macroeconomic stability. This paper examined the broad money demand function and its stability in two West African countries as Ghana and Cote d'Ivoire. With more than four decades two streams of thought have dominated literature, namely classics and Keynesians. These different approaches or school of thought focus on the velocity hypothesis implications in setting the reasons that motivate households for holding money.

Neoclassical opinion is based on the hypothesis of constant velocity. This statement considered money as neutral. So it implies a dichotomy between monetary and real areas because only transaction motive explains the demand of money. All these ideas are summarised under the quantity theory of money. Irving Fisher (1911) by an equation of exchange pointed out that the money is neutral. When the quantity of money varies, the equilibrium price (general price level) moves in the same proportion. In other words, money is just a simple instrument that facilitates transactions. Then Money hasn't an intrinsic or own utility. Behind this theory, this author attributes only one role to money in economy that is an instrument of transaction. More precisely, money doesn't impact real variables like GDP, labour size force and capital stock. Moreover, considering that the quantity of money is exogenous, it's impossible that nominal income or price determines the quantity of money. But the principal weakness of Irving Fisher work is that the concept of demand for money is not even mentioned. The Cambridge school integrated the concept of money demand in their analytical framework in explaining the influence of money supply on price level. In their works, Marshall (1923) and Pigou (1917) adopted income approach instead of transaction approach like Irving Fisher. According to these authors, the portion of income held in term of monetary can be allocated to current transactions and future payments (store of value). In this context, the wealth and the interest rate might become the major explanatory variables of money demand. However, this school of thought doesn't reject the quantity theory. As proof, if we have full employment (maximum production) and fixity of income velocity, the price level responds proportionally to the variations in quantity of money.

A modern version of this theory has been evolved by monetarist school leaded by Milton Friedman. By extending the uses of money holding (deposits), he suggests three explanatory variables in the money demand that are interest rate, permanent revenue and the price level. Friedman (1956) argued that money is one of multiple forms in which economic agents hold their wealth. This approach suggested several determinants of demand of money. Among these determinants are the permanent income, the interest rate, the price level and the tastes and preferences of economic actors. Friedman tried to enlarge the factors explaining the money demand without denying the basis of quantity theory. In Friedman's opinion, besides its impact on price level, the quantity of money influences real income in short run. But in long run, an expansive monetary policy has negative effects on real revenue (activities) and generates inflation. In brief, Friedman recommended a strict monitoring of money quantity growth rate which must equal to the national production growth rate.

On contrary to neoclassical vision, Keynes considered that the velocity is moving and the money isn't neutral. For him it exists some links between monetary and real activities. This author introduces the motivation of speculation as a reason of holding money by households. According to Keynes, the interest rate, purchasing power and the price are the main explanatory variables of demand of money. Keynes $(1930,1936)$ suggested three motives that determine the behaviour of economic agents to hold money which are the transaction, precautionary and speculative motives. However, the principal particularity of Keynes analysis is the introduction of speculative motive. This motive is also called the liquidity preference theory. Indeed, the uncertainty about the future plays an important role in explaining the money demand. This risk relative to the future value of assets pushes Keynes to introduce the future level of the interest rate in setting the demand money function. Keynes also developed the concept of «liquidity trap». For Keynes, «liquidity trap» appears when the elasticity of money demand is infinite at low levels of interest rate. Opposed to the principle of dichotomy between the monetary and real variables, Keynes recommended monetary instrument to stimulate economic activity. In other words, expansive monetary policy can play the same role as the budget policy in a context of 
economic crisis.

However, at the end of the 1970s, certain unanimity appears in connection with the determinants of the demand for money. This consensus is still broken in the early 1980s with the emergence of new fields of the demand for money (Arestis and Demetriades 1991).Concerning high income countries, there are plenty body of literature about money demand and its stability. See Choi and Cook (2007) for the USA; Jung (2016) for the Euro area; Tang (2013) for Japan; Drake and Chrystal (1994) for the UK; Kia (2006) for Canada; Kumar and Webber (2013) for Australia. Coming back to emerging markets, large research has been performed. See Niyimbanira (2013) for South Africa; Wang (2017) for China; Sriram (2002) for Malaysia; Zannah, Ramly and Mahat (2017) for India; Deckle and Pradhan (1997) for Asian countries among others. For low income countries such as sub-Saharan African countries there are considerable literature. See Imimole and Uniamikogbo (2014) for Nigeria; Djeto and Pourgerami (1990), Drama and Shen (2011) for Cote d'Ivoire; Nchor and Adamec (2016), Insah, Ofori-Boateng and Ohemeng (2013) for Ghana; Most of authors mentioned above generally utilize the cointegration framework developed by (Johansen S., 1988) and (Johansen, S. and Juselius K., 1990) and error correction model (ECM). All results are quite similar there is long relationship between money demand and its determinants both for high and low income countries.

\section{Empirical Model Specification, Methodology Applied and Data Sources}

\subsection{Model Specification and Methodology Applied}

There are several theoretical justifications to expect a relationship between money demand and it determinants, Baumol (1952), Tobin (1956), Friedman (1956), Ericsson and Sharma (1996) among others. To explore the stability of money demand in Ghana and Cote d'Ivoire, our analysis is based on the model used by Handa (2000) and Thomas (1985).Therefore, the following econometric models is specified as follow:

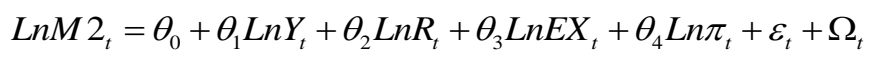

Where $M 2_{t}, Y_{t}, R_{t}, E X_{t}$ and $\pi_{t}$ are respectively money demand, output, interest rate, exchange rate and inflation. Also $\Omega_{t}$ is dummy variable to capture other factors that affect money demand. This paper employed annual data for the period 1980 to 2014 . The a priori expectations for the coefficients are.

$$
\theta_{1}>0, \theta_{2}<?, \theta_{3}<?, \theta_{4}>0
$$

\subsection{Methodology Applied and Data Sources}

Prior to testing for cointegration, the time series properties of the variables need to be examined. Non-stationary time series data has often been regarded as a problem in empirical analysis. In so doing the standard augmented Dickey-Fuller test (Dickey F., 1979) and (Phillips-Perron, 1988) are performed to test the existence of unit root in order to establish the properties of individual series. Second, to examine the stability of money demand in the selected countries, this study uses recent co-integration analysis approach, known as autoregressive-distributed lag (ARDL) model, Pesaran et al. (2001). Pesaran et al. (2001) cointegration approach, is also known as Bounds testing technique. According to The ARDL unrestricted function is written as follow:

$$
\begin{aligned}
& \Delta L n M 2_{t}=\theta_{0}+\sum_{i=1}^{n} \theta_{1 i} \Delta L n M 2_{t-1}+\sum_{i=0}^{n} \theta_{2 i} \Delta L n Y_{t-i}+\sum_{i=0}^{n} \theta_{3 i} \Delta L n R_{t-i}+\sum_{i=0}^{n} \theta_{4 i} \Delta L n E X_{t-i}+\sum_{i=0}^{n} \theta_{5 i} \Delta L n \pi_{t-i}+v_{t} \\
& \Delta L n M 2_{t}=\theta_{0}+\sum_{i=1}^{n} \theta_{1 i} \Delta \operatorname{Ln} M 2_{t-1}+\sum_{i=0}^{n} \theta_{2 i} \Delta \operatorname{Ln} Y_{t-i}+\sum_{i=0}^{n} \theta_{3 i} \Delta \operatorname{Ln} R_{t-i}+\sum_{i=0}^{n} \theta_{4 i} \Delta \operatorname{LnEX} X_{t-i}+\sum_{i=0}^{n} \theta_{5 i} \Delta \operatorname{Ln} \pi_{t-i}+\delta_{1} \operatorname{LnM} 2_{t-1}+\delta_{2} \operatorname{Ln} Y_{t-1}
\end{aligned}
$$

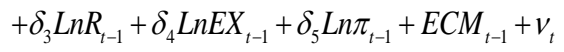

Where, the short-run dynamic parameters $\theta_{1}$ to $\theta_{5}$ convergence to equilibrium, and $\delta_{1}$ to $\delta_{5}$ are the long-run multipliers of the underlying ARDL model. Testing the existence of a long-run relationship can be conducted by examining the joint null hypothesis $H_{0}$ that: $H_{0}: \delta_{1}=\delta_{2}=\delta_{3}=\delta_{4}=\delta_{5}=0$ against the alternative $H_{1}$ that $H_{1}: \delta_{1} \neq \delta_{2} \neq \delta_{3} \neq \delta_{4} \neq \delta_{5} \neq 0$.

The F-test is used to test the existence of long-run relationships. Thus, the Pesaran et al. approach computes two sets of critical values for a given significance level. One set assumes that all variables are $I(0)$ and the other set assumes they are all $I(1)$. If the computed F-statistic exceeds the upper critical bounds value, then the $H_{0}$ (null hypothesis) is rejected. If the F-statistic falls into the bounds, then the test becomes inconclusive. Lastly, if the F-statistic is below the lower critical bounds value, it implies no co-integration. When long-run relationship exists, the F-test indicates which variable should be normalized. Moreover, when the order of integration of the variables is known and if all the variables are $I(1)$, then the decision is based on the upper bound value. Similarly, 
if all the variables are $I(0)$, then the decision is based on the lower bound. After estimation of long run relationship by employing the selected ARDL model, there are varieties of diagnostic and stability tests to make sure our model is stable. In so doing we perform serial correlation, heteroscedasticity and cumulative sum squares of recursive residuals (CUSUMSQ).

Third, the time series data used for our paper was selected from the World Development Indicators data bank. Where $M_{2}$ (broad monetary aggregate) is used as a measure of money stock. Gross Domestic Expenditure (in constant 2000 prices) is used as the real income $\left(Y_{t}\right)$ variable and is also known as the scale variable. The interest rate we utilize is the market discount rate $\left(R_{t}\right)$ instead of nominal interest rate because it's only the rate available in IMF data base. In contrast with existing studies on the subject, the present paper includes the inflation rate $\left(\pi_{t}\right)$ and the real effective exchange rate $\left(E X_{t}\right)$ in the model.

\section{Empirical Results and Interpretation}

To avoid problems of spurious regression, we first start by examining the stationarity properties of the data base. So we perform a traditional units root tests by applying the Augmented Dickey Fuller (ADF) and Philips-Perron (PP) tests. The results are presented in table 1 below.

Table 1. Unit roots test

\begin{tabular}{|c|c|c|c|c|c|}
\hline Countries & Variables & ADF Statistics & Order of integration & PP Statistics & Order of integration \\
\hline \multirow{5}{*}{$\begin{array}{l}\text { Cote } \\
\text { d'Ivoire }\end{array}$} & $\operatorname{LnM} 2$ & -0.660 & $I(1)$ & -5.544 & $I(1)$ \\
\hline & $\operatorname{Ln} Y$ & -3.391 & $I(1)$ & -3.456 & $I(1)$ \\
\hline & $\operatorname{LnR}$ & -5.891 & $I(1)$ & -5.893 & $I(1)$ \\
\hline & LnEX & -6.107 & $I(1)$ & -6.157 & $I(1)$ \\
\hline & LnIF & -4.048 & $I(1)$ & -4.068 & $I(1)$ \\
\hline \multirow{5}{*}{ Ghana } & $\operatorname{LnM} 2$ & -5.92 & $I(1)$ & -4.787 & $I(1)$ \\
\hline & $\operatorname{Ln} Y$ & -3.351 & $I(1)$ & -3.240 & $I(1)$ \\
\hline & LnR & -7.559 & $I(1)$ & -7.520 & $I(1)$ \\
\hline & LnEX & -5.992 & $I(1)$ & -5.992 & $I(1)$ \\
\hline & LnIF & -5.326 & $I(1)$ & -5.386 & $I(1)$ \\
\hline
\end{tabular}

Source: Own Computation.

(a) McKinnon (1991) critical values are used for rejection of the null unit root.

(b) $\mathrm{I}(0)=$ The variable is stationaryat level, $\mathrm{I}(1)=$ A variable is integrated of order one.

Critical value for $\mathrm{ADF}: * 1 \%$ and $* * * 10 \%$ are -3.7343 and -2.6348 respectively.

The results from augmented Dickey-Fuller (1979) and Phillips-Perron (1988) tests show that we fail to reject the stationary null hypothesis at level but all data are all first difference stationary see Table 1.Thus, according to the empirical foundation, we found that all variables follow the $I(1)$ process. Then we perform the ARDL (Autoregressive Distributive Lag Model) procedure to test the cointegration relationship both in long and short run. The results are depicted in Table 2 below:

Table 2. Critical value bounds of the statistic: unrestricted intercept and no trend with $k=5$

\begin{tabular}{llll}
\hline Countries & F-Statistics=135,06 & & \\
\hline \multirow{3}{*}{ Cote d'Ivoire } & Critical values & Lower I(0) & Upper I(0) \\
& $1 \%$ & 3.41 & 3.41 \\
& $5 \%$ & 2.62 & 2.62 \\
Ghana & $10 \%$ & 2.26 & 2.26 \\
& F-Statistics=326,54 & & 4.68 \\
& $1 \%$ & 3.41 & 3.79 \\
\hline
\end{tabular}

Source: Own Computation.

Note. critical values are extracted from Narayan (2004a, b, 2005a) $k$ is the number of regressors.

We found that the calculated F-statistics for both countries are bigger than the upper bounds values; however the null hypothesis is rejected and concludes the existence of cointegration relationship between our variables. 
Having found a long run relationship between money demand and their determinants in both countries, the long-run elasticities based on equation (2) above are estimated for each economy respectively. Table 3 and table 4 display the results of two selected countries.

Table 3. Estimated long run elasticities using the ARDL approach

\begin{tabular}{lccccc}
\hline Countries & Variables & Coefficient & Std. Error & t-Statistic & Prob. \\
\hline \multirow{3}{*}{ Cote d'Ivoire } & LNY & 1.500 & 0.4791 & $3.130^{* * *}$ & 0.004 \\
& LNR & -0.104 & 0.078 & -1.328 & 0.195 \\
& LNEX & 0.633 & 0.262 & $2.413^{* * *}$ & 0.022 \\
LN $\pi$ & 0.954 & 0.188 & $5.081^{* * *}$ & 0.000 \\
D1 & 0.258 & 0.169 & 1.520 & 0.140 \\
D2 & 0.020 & 0.162 & 0.125 & 0.901 \\
D3 & 0.133 & 0.156 & 0.854 & 0.400 \\
& C & -23.411 & 13.40 & -1.746 & 0.092 \\
\hline
\end{tabular}

Source: Own Computation.

$R^{2}=0.96, \bar{R}^{2}=0.95 \operatorname{Pr} o b(F-$ statistic $)=0.000 ; \quad(F-$ statistic $)=100.36 ; n=35$

The asterisks $* * *, * *$ and $*$ implies statistically significant at $1 \%, 5 \%$ and at $10 \%$ level respectively. Note that $D_{l}, D_{2}$ and $D_{3}$ are dummy variables that capture all factors that affect money demand in Cote d'Ivoire.

Table 4. Estimated long run elasticities using the ARDL approach

\begin{tabular}{clllll}
\hline Countries & Variables & Coefficient & Std. Error & t-Statistic & Prob. \\
\hline \multirow{3}{*}{ Ghana } & LNY & 1.902 & 0.295 & $6.427^{* * *}$ & 0.000 \\
& LNR & 0.362 & 0.111 & $3.253^{* * *}$ & 0.003 \\
& LNEX & -0.070 & 0.074 & -0.936 & 0.357 \\
& LN $\pi$ & 0.840 & 0.086 & $9.760^{* * *}$ & 0.000 \\
& D1 & 0.049 & 0.248 & 0.201 & 0.842 \\
& D2 & 0.016 & 0.161 & 0.09 & 0.921 \\
& D3 & -0.307 & 0.155 & $-1.974^{*}$ & 0.08 \\
& C & -2.451 & 6.675 & $-4.112^{* * *}$ & 0.0003 \\
\hline
\end{tabular}

Source: Own Computation.

$R^{2}=0.998 ; \bar{R}^{2}=0.997 ; \operatorname{Pr} o b(F-$ statistic $)=0.000 ; F-$ statistic $=293.68 ; n=35$

The asterisks ***,** and * implies statistically significant at $1 \%, 5 \%$ and at $10 \%$ level respectively. Note that $D_{l}, D_{2}$ and $D_{3}$ are dummy variables which capture all factors that affect money demand in Cote d'Ivoire.

From Table 3 all coefficients are correctly signed. The results indicated that, real income, exchange rate and expected inflation have positive and significant impact on money aggregate, in the long-run during the period of study. There is a positive and significant relationship between broad money demand and real income during the period of study, as the income elasticity is statistically significant. This implies that an increase in real income leads to increase in the demand for money as predicted by economic theory. This signifies also that the long run elasticity of real income is elastic; therefore, a percentage point increase in real income causes money aggregate to increase by 1.5 percentage point. Moreover, nominal interest rate has negative impact on money aggregate in the long run; this shows that as interest rate increases by one point, demand for money aggregate decreases by 1.104 , but this impact is not statistically significant. There is also a positive and statistically significant relationship between broad money demand and real exchange rate during the same period. The relationship is consistent with theory that predicts that depreciation of domestic currency (increase in exchange rate) can be perceived as an increase in the demand for domestic money in long-run. Also inflation rate has a positive sign and is consistent with our expectation. This signifies that money demand will increase by 0.95 if price level rises by $1 \%$. This result shows that, higher is the rate of expected inflation, and higher is the demand for broad money ceteris paribus. In fact, economic agents need more currency holdings for their transactions, when the market prices increase. The obtained $R^{2}=0.96$ in the model implies that the explanatory variables included in the model explain 96 percent of all variations in money demand in Cote d'Ivoire. The Probability of rejecting the model specification given by Prob (F-statistics) of 0.000 reflects that the model is well specified. In case the model is adjusted the $\bar{R}^{2}$ will be reduced to 0.95 percent, which still preferable in explaining the model variation and 
thus according to the result we can accept the null hypothesis that there is long-run relationship between money demand and it determinants. Therefore, the long run expected inflation, real income and real exchange rate are significant factors that influence demand for money aggregate in Cote d'Ivoire.

Table 4 above shows the results of the coefficient of the long run relationship among the variables and all coefficients are also correctly signed excepted domestic interest rate $R_{t}$ which displays positive sign. There is a positive and statistically significant relationship between broad money demand and real income during the period of study, as the income elasticity is statistically significant. This implies that an increase in real income leads to increase in the demand for money as predicted by economic theory. This signifies also that the long run elasticity of real income is elastic; therefore, a percentage point increase in real income causes money aggregate to increase by 1.9 percentage point for Ghana. Moreover, the impact of nominal domestic interest rate is inelastic; hence, a percentage point increase in domestic interest rate causes money aggregate to increase about 0.36 percentage point. From the table, the impact of exchange rate is inelastic; therefore, a percentage point increase in exchange rate causes money to decrease about 0.07 percentage point but statistically inefficient. In other words, an appreciation of local currency leads to increase money demand. In addition, the impact of expected inflation is inelastic and significant; so, an increase in expected inflation causes money aggregate to increase about 0.84 . The obtained $R^{2}=0.998$ in the model implies that the explanatory variables included in the model explain 99.8 percent of all variations in money demand in Ghana. The Probability of rejecting the model specification given by Prob (F-statistics) of 0.000 reflects that the model is well specified. In case the model is adjusted the $\bar{R}^{2}$ will be reduced to 99.7 percent, which still preferable in explaining the model variation and thus according to the result we can accept the null hypothesis that there is long-run relationship between money demand and it determinants. Therefore, in the long run expected inflation and real income are significant factors that influence demand for money aggregate in Ghana.

Furthermore, the stability test is performing to check the parameters of our model are stable or not. In so doing, the CUSUMSQ test (Brown, Durbin and Evans, 1975) is run and the results are shown in figure 1 below.

Cote d'Ivoire

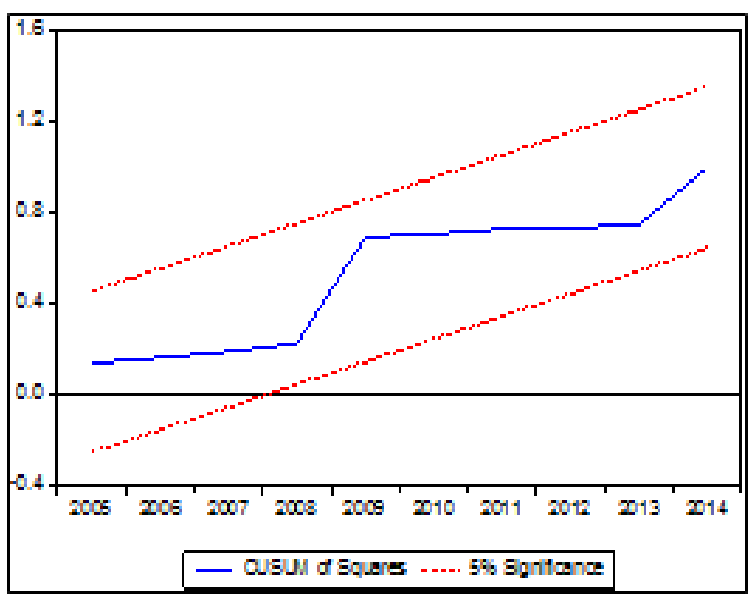

Ghana

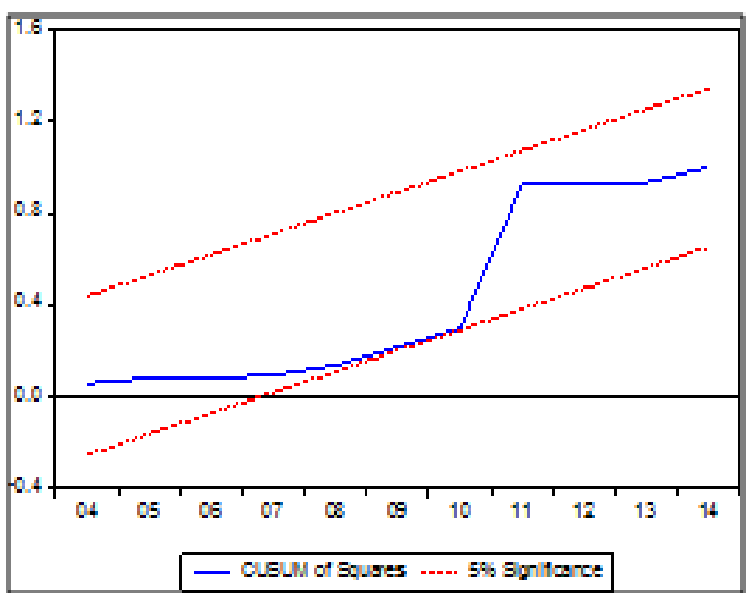

Figure 1. Stability test for Cote d'Ivoire and Ghana

Source: Own Computation.

From figure 1 and table 3 and 4 above, the coefficients of determination of both countries are acceptable with significant F-statistic. The model appears generally stable and well specified given the plots of CUSUM of Squares (see figure 1 above), even though in the case of Ghana, this statistic seems to be crossing the lower band marginally during the period 2009-2010. So we conclude that cointegration relationship exists between money demand and its determinants in both countries during the period of the study. Finally the vector error correction model (VECM) is utilized to examine the short run dynamic relationships. Before that it is necessary for us to determine the appropriate lag length (k) prior to conducting the vector error correction model (VECM) tests. The results are shown in table 5 below. 
Table 5. VAR lag order selection criteria

\begin{tabular}{lccccccc}
\hline & Lag & LogL & LR & FPE & AIC & SC & HQ \\
\hline \multirow{3}{*}{ CIV } & 0 & 85.35100 & NA & $1.17 \mathrm{e}-08$ & -4.084437 & -3.168352 & -3.780781 \\
& 1 & 259.7575 & $250.7094^{*}$ & $1.10 \mathrm{e}-12^{*}$ & -13.42235 & $-11.36115^{*}$ & $-12.73912^{*}$ \\
& 2 & 280.8647 & 23.74554 & $1.78 \mathrm{e}-12$ & -13.17904 & -9.972744 & -12.11624 \\
& 3 & 312.7512 & 25.90777 & $2.07 \mathrm{e}-12$ & $-13.60945^{*}$ & -9.258044 & -12.16708 \\
\multirow{4}{*}{ GHANA } & 12.52718 & NA & $1.10 \mathrm{e}-06$ & 0.467051 & 1.383136 & 0.770707 \\
& 1 & 215.5259 & $291.8107^{*}$ & $1.75 \mathrm{e}-11^{*}$ & -10.65787 & $-8.596679^{*}$ & $-9.974643^{*}$ \\
& 2 & 243.3879 & 31.34471 & $1.86 \mathrm{e}-11$ & -10.83674 & -7.630445 & -9.773946 \\
& 2 & 270.1454 & 21.74046 & $2.97 \mathrm{e}-11$ & $-10.94659^{*}$ & -6.595182 & -9.504219 \\
\hline
\end{tabular}

Source: Own Computation.

* indicates lag order selected by the criterion, LR: sequential modified LR test statistic (each test at 5\% level), FPE: Final prediction error, AIC: Akaike information criterion, SC: Schwarz information criterion, HQ: Hannan-Quinn information criterion.

The short-run dynamics of money demand stability function in Cote d'Ivoire and Ghana is analysed by computing an error-correction model $(\mathrm{ECM})$ with lags length $(\mathrm{k}=1)$. Table 6 below reports the results of VECM formulation.

Table 6. Short-run ADRL estimation $(\mathrm{k}=1)$

\begin{tabular}{llccc}
\hline Countries & Variables & Coefficients & Standard Error & T-statistic \\
\hline \multirow{4}{*}{ Cote d'Ivoire } & DLNM2(-1) & 0.015 & 0.284 & 0.051 \\
& DLNY(-1) & -0.291 & 0.638 & -0.456 \\
& DLNR(-1) & 0.07 & 0.131 & 0.534 \\
& DLNEX(-1) & -0.146 & 0.241 & 0.604 \\
& DLN $\pi(-1)$ & 0.461 & 0.485 & 0.951 \\
& ECT(-1) & -0.069 & 0.345 & -3.101 \\
& Constant & 0.006 & 0.485 & 0.239 \\
& $R^{2}=0.48 ; \bar{R}^{2}=0.36 ; F-$ statistic $=3.89 ; n=35$ & & 0.143 \\
Ghana & DLNM2(-1) & 0.027 & 0.190 & -1.800 \\
& DLNY(-1) & -1.008 & 0.559 & 1.706 \\
& DLNR $(-1)$ & 0.136 & 0.079 & -1.681 \\
& DLNEX $(-1)$ & -0.081 & 0.048 & 0.265 \\
& DLN $\pi(-1)$ & 0.392 & 0.147 & -1.465 \\
& ECT $(-1)$ & -0.039 & 0.027 & 4.928 \\
& Constant & 0.329 & 0.067 & \\
& $R^{2}=0.31 ; \bar{R}^{2}=0.15 ; F-$ statistic $=1.957 ; n=35$ & & & \\
\hline
\end{tabular}

Source: Own Computation.

Finally, after computing the long-run cointegration relationships using the ADRL method, the short-run dynamics of the long-run money demand function is analysed by computing an error-correction model (ECT). The results are summarized in table 6 above. We found that money demand function in Cote d'Ivoire displays a correct sign (negative) and relatively consistent coefficient (-0.069) at the conventional level. This implies that the adjustment process to an exogenous shock is rather acceptable. In other words, the coefficient of the feedback parameter is -0.069 and it suggests that when broad money balances exceed their long-run relationships, they adjust downwards at a rate of about 6.9 percent. This result also means that money demand is stable both in short and long-run in Cote d'Ivoire.

In addition, Table 6 also presents the short run dynamic relationship among the variables and the set of short run coefficients in the vector error correction model, VECM for Ghana. The coefficient of the speed of adjustment is negative (-0.039) but not significant at the conventional level. This shows that there is 3.9 percentage point adjustment taking place each year towards the long run period. However, the adjustment towards the long run period is not very stable over the period. Therefore, demand for money aggregate is unstable in short-run but stable in long run.

\section{Conclusion}

The main target of this paper was to analyse the broad money demand function for two West African countries 
(Cote d'Ivoire and Ghana) for the period 1980 to 2015 using the Autoregressive Distributed Lag (ARDL) procedure proposed by Pesaran et al. (2001). The empirical result shows that a long-run relationship exists between the broad money demand, real gross domestic product, interest rate, real exchange rate and inflation rate for both countries cited above. The result also indicates that in the long-run, real gross domestic product and inflation rate are significant determinants of broad money demand in both Cote d'Ivoire and Ghana. From the estimated coefficients it is clear that real income seems or tends to be the most significant factor determining the demand for broad money in both countries. The results further demonstrate that the broad money demand function for both countries is stable over the sample period, and validate the use of $M_{2}$ monetary aggregate for monetary policy implementation. Our results link with the previous works and consistent with our main hypothesis. In addition, the short run result of our empirical investigation is statistically significant for Cote d'Ivoire and insignificant for Ghana at the conventional level. This means that money demand is stable for Cote d'Ivoire in short run and unstable for Ghana in the same period. It is recommended that monetary policy authorities should continue to implement policies that will reinforce macroeconomic stability and facilitate economic growth.

\section{References}

Arestis, P., \& Demetriades, P. (1991). Cointegration, error-correction and the demand for money in Cyprus. Applied Economics, 23, 1417-24. https://doi.org/10.1080/00036849100000192

Arize, A. C., \& Shwiff, S. S. (1993). Cointegration, Real Exchange Rate and Modelling the Demand for Broad Money in Japan. Applied Economics, 25(6), 717-26. https://doi.org/10.1080/00036849300000124

Baumol, W. J. (1952). The transactions Demand for Cash: An Inventory Theoretic Approach. The Quartely Journal of Econometrics, 66, 545-56. https://doi.org/10.2307/1882104

Brown, R. L., Durbin, J., \& Evans, J. M. (1975). Techniques for testing the constancy of regression relations over time. Journal of the Royal Statistical Society, 37(Series B), 149-192.

Choi, W. G., \& Cook, D. (2007). Financial Market Risk and U.S. Money Demand. IMF Working Papers, No. $07 / 89$.

Deckle, P., \& Pradhan, M. (1997). Financial Liberalization and Money Demand in Asean Countries: Implications for Monetary Policy. IMF Working Paper WP/97/36. https://doi.org/10.5089/9781451845419.001

Dickey, D. A., \& Fuller, W. A. (1979). Distribution of the Estimators for Autoregressive Times Series with a Unit Root. Journal of the American Statistical Association, 74(366), 427-431. https://doi.org/10.2307/2286348

Djeto, A., \& Pourgerami, A. (1990). Dependance and Stability of the Demand for Money in Small Open Economy: The Case of Côte d'Ivoire. African Development Review, 2(1), 52-66. https://doi.org/10.1111/j.1467-8268.1990.tb00018.x

Drake, L., \& CHrystal, A. K. (1994). Compagny-Sector Money Demand: New Evidence on the Existence of a Stable Long-Run Relationship for the United Kingdom. Journal of Money, Credit, and Banking, 26(3), 479-94. https://doi.org/10.2307/2078013

Drama, B. G. H., \& Yao, S. (2011). Demand for Money in Côte d'Ivoire: Evidence from the cointegration test. International Journal of Economies and Finance, 3(1), 188-197.

Ericsson, N. R., \& Sharma, S. (1996). Broad Money Demand and Financial Liberalization in Greece. IMF Working, Paper, No. WP/96/62 (Washington: International Monetary Fund, June 1996).

Fisher, I. (1911). The Purchasing Power of Money. New York: Mcmillan.

Friedman, M. (1956). Quantity theory of Money. Chicago.

Friedman, M. (1959). The demand for money: Some Theoretical and Empirical Results. Journal of Political Economy. https://doi.org/10.1086/258194

Friedman, M., \& Schwartz, A. J. (1982). Monetary trends in the United States and the United Kingdom. Chicago: University of Chicago Press. https://doi.org/10.7208/chicago/9780226264257.001.0001

Handa, J. (2000). Monetary Economics (p. 766). London, U.K.: Routledge, 2000. https://doi.org/10.4324/9780203456910

Haug, A. A., \& Lucas, R. F. (1996). Long-term money demand in Canada: in search of stability. The Review of Economics and Statistics, 78, 345-48. https://doi.org/10.2307/2109938

Immole, B., \& Uniamikogbo, S. O. (2014). Testing for the Stability of Money Demand Function in Nigeria. 
Journal of Economics and Sustainable Development, 5(6).

Insah, B., Ofori-Boateng, K., \& Ohemeng, W. (2013). A Dynamic Analysis of the Demand for Money in Ghana. .African Journal of Social Sciences, 3(2), 19-29.

Johansen, S. (1988). Statistical Analysis of Cointegration vectors. Journal of Economic Dynamics and Control, 12(2-3), 231-254. https://doi.org/10.1016/0165-1889(88)90041-3

Johansen, S., \& Juselius, K. (1990). Maximum likelihood estimation and inference on cointegration-with applications to the demand of money. Oxford Bulletin of Economics and Statistics, 52(2). https://doi.org/10.1111/j.1468-0084.1990.mp52002003.x

Jung, A. (2016). A portfolio demand approach for broad money in the euro area. Working Paper Series, No. 1929/July 2016, European Central Bank.

Keynes, J. M. (1930). A Treatise on Money. London and New York: Macmillan, 1930.

Keynes, J. M. (1936). The General Theory of Employment, Interest and Money. London and New York: Macmillan, 1936.

Kia, A. (2006). Economic policies and demand for money: Evidence from Canada. Applied Economics, 38(12), 1389-1407. https://doi.org/10.1080/00036840600684879

Kumar, S., \& Webber, D. (2013). Australasian money demand stability: Application of structural break tests. Applied Economics, 45(8), 1011-1025. https://doi.org/10.1080/00036846.2011.613788

Marshall, A. (1923). Money, Credit and Commerce. London: Macmillan, 1923.

McKinnon, J. G. (1991). Critical Values for Co-Integration Tests. In R. F. Engle, \& C. W. J. Granger (Eds.), Long-Run Economic Relationships (pp. 267-276). Oxford University Press.

McNown, R., \& Wallace, M. S. (1992). Cointegration tests of a long-run relation between money demand and the effective exchange rate. Journal of International Money and Finance, 11(1), 107-114. https://doi.org/10.1016/0261-5606(92)90024-R

Mishkin, F. S. (2013). Economics of Money, Banking and Financial Markets. Pearson Education, 2013.

Narayan, P. K. (2004). Reformulating Critical Vlues for the Bounds F-statistics Approach to Cointegration: An Application to the Tourism Demand Model for Fiji. Discussion Papers, Department of Economics, Monash University, Victoria, Australia.

Narayan, P. K. (2005a). The structure of tourist expenditure in Fiji: Evidence from unit root structural break tests. Applied Economics, 37, 1157-1161. https://doi.org/10.1080/00036840500109373

Narayan, P. K. (2005b). The saving and investment nexus for China: Evidence from cointegration tests. Applied Economics, 37, 1979-1990. https://doi.org/10.1080/00036840500278103

Nchor, D., \& Adamec, V. (2016). Investigating the Stability of Money Demand in Ghana. Procedia-Social and Behavorial Sciences, 220(2016), 288-293. https://doi.org/10.1016/j.sbspro.2016.05.501

Niyimbanira, F. (2013). Money Demand in South Africa Revisited: A detailed Analysis of Different models. International Business and Economics Research Journal, 12(4). https://doi.org/10.19030/iber.v12i4.7741

Pesaran, M. H., Shin, Y., \& Smith, R. J. (2001). Bounds Testing Approaches to the Analyis of Level Relationships. Journal of Applied Econometrics, 16(3), 289-326. https://doi.org/10.1002/jae.616

Phillips, P. C. B., \& Perron, P. (1988). Testing for a Unit Root in Time Series Regression. Biometrika, 75, 335-346. https://doi.org/10.1093/biomet/75.2.335

Pigou, A. C. (1917). The value of Money. Quartely Journal of Economics, 32(1), 38-65. https://doi.org/10.2307/1885078

Polak, J. (1957). Monetary Analysis of Income Formation and Payments Problems. Staff Papers, International Monetary Fund, 6(November), 1-50. https://doi.org/10.2307/3866128

Polak, J., \& Argny, V. (1971). Credit Policy and the Balance of Payments. Staff Papers, International Monetary Fund, 16, 1-24. https://doi.org/10.2307/3866373

Sriram, S. S. (2001). A survey of recent Empirical Money Demand Studies. Staff Papers, International Monetary Fund, 47(3), 334-365.

Tang, C. F. (2013). Evidence on Structural Instability in the Japanese Money Demand Function. Margin: The 
Journal of Applied Economic Research, 7(3), 255-272. https://doi.org/10.1177/0973801013491531

Thomas, L. (1985). Portfolio Theory and Currency Substitution. Journal of Money, Credit and Banking, 17(3), 347-357. https://doi.org/10.2307/1992629

Tobin, J. (1956). The Interest-Elasticity of Transaction Demand for Cash. Review of Economics and Statistics, 38(August 1956), 241-47. https://doi.org/10.2307/1925776

Wang, Y. Q. (2017). Demand for Money in China with Currency Substitution: Evidence from the Recent Data. Modern Economy, 8, 484-493. https://doi.org/10.4236/me.2017.84036

Zannah, M., Ramly, A., \& Mahat, F. (2017). Determinant of money demand in India. Qualitative and Quantitative Research Review, 2(2).

\section{Copyrights}

Copyright for this article is retained by the author(s), with first publication rights granted to the journal.

This is an open-access article distributed under the terms and conditions of the Creative Commons Attribution license (http://creativecommons.org/licenses/by/4.0/). 